\title{
Esfera pública y construcción del mundo común El relato dislocado
}

\author{
Cristina PEÑAmarín* \\ cpberis@ucm.es
}

\begin{abstract}
(Abstracts y palabras clave al final del artículo)
Enviado: 20 de abril de 2013

Evaluado: 26 de junio de 2013

Aceptado: 1 de agosto de 2013
\end{abstract}

Las narraciones han circulado siempre de la palabra hablada a la escrita y a la inversa; de la literatura a la pintura, el cine o el comic, aunque la expresión "narraciones transmediáticas", o transmedia para abreviar, hace pensar en un fenómeno nuevo, en algo que se ha producido en este tiempo de hipermediaciones. Si bien la cualidad mudable y viajera es propia de todo relato, la proliferación actual de mundos narrativos que se despliegan en secuelas, precuelas, series intercaladas, etc., combinando todo tipo de artilugios, es tan nueva y singular como la revolución tecnológica que vivimos. Una transformación de la información y la comunicación donde surgen inesperadas formas de desarrollar el permanente interés de las audiencias por participar en las narraciones y por recrearlas, en particular las que desarrollan mundos conocidos, aunando la fascinación que produjo en los receptores el original relato matriz, con la familiaridad que genera su re-visitación en las piezas que le suceden.

Tan relevante culturalmente como esa capacidad de expansión de un mundo narrativo y un relato en muchos otros es su simétrico potencial de condensación - extraordinariamente potenciado también por las tecnologías y los usos actuales de la comunicación sincrónica de imágenes y sonidos, aunque no puedo pretender entrar aquí en ello. Quienes entienden un enunciado del tipo "eso supone comer del árbol prohibido" captan la metáfora porque conocen el relato bíblico de Adán y Eva, que acude a su mente como una imagen o una viñeta capaz de iluminar una situación actual y estructurar su sentido, de un modo que muestra que entre relato, metáfora e imagen se pueden dar fronteras muy fluidas.

Seguramente viajan sobre todo los relatos más logrados, los más ricos en sugerencias, más capaces de potenciar la imaginación, los afectos y la reflexión de los receptores. Como el de Adán y Eva, que contiene un modelo acabado de interacción

* Catedrática de Teoría de la Información en la Universidad Complutense de Madrid. 
dual mediada por un tercero, la serpiente introductora de cierta idea imprevista y con ella de la duda y la posibilidad de alternativa al orden dado. Este relato y la metáfora en que se condensa se abren, como siempre hacen relatos y metáforas, a múltiples interpretaciones (pecado, desobediencia, ambición humana de saber, desafío a la autoridad, al monologismo, etc.), dependiendo de la enciclopedia del intérprete y de sus intereses, las preguntas que le sugiera su lectura. Al margen de significados religiosos codificados, diría que sugiere que la pareja edénica pierde la inocencia antes de comer del árbol prohibido, cuando vislumbra que puede haber formas de ver el mundo diferentes de la dada y sancionada por la divinidad, cuando concibe que el mundo no es un paraíso comprensible desde una única ley y una sola lógica. Una interpretación, claro está, sesgada por ciertos intereses actuales. Como delatan algunas expresiones -alternativa al orden, interpretaciones múltiples, monologismo-, inspirada por voces, discursos, lugares comunes más o menos identificables. Ninguna interpretación puede darse sin alguna variante de ellos. Pero de algunas interpretaciones se puede decir que no corresponden al Lector Modelo previsto por el texto (Eco), o que construyen un nuevo cierre y cambian el relato original. Si eso ocurre es porque esa lectura del relato, al entrar en relación con las preocupaciones, conocimientos e intereses de su intérprete, le sugiere una versión-transformación de la que ese intérprete se hace narrador, para sí mismo o para otros. La identidad del relato es maleable, además de las de expandirse y condensarse, tiene la propiedad de transformarse en otro en su interpretación y reiteración, o convertirse en un híbrido que es y no es el mismo relato de partida.

Aquí me interesan sobre todo los relatos sobre el mundo común, el mundo que construimos conjuntamente y que, para $\mathrm{H}$. Arendt, es el objeto de la política. Me interesa preguntarme qué relatos tenemos sobre él y si los que tenemos potencian nuestras posibilidades de comprender, de imaginar alternativas o de reflexionar sobre los problemas comunes. Se dice que la información mediática, las noticias, cuentan historias sobre nuestro mundo. Las noticias son casi-narraciones constitutivamente transmediáticas. Su razón de ser es pasar desde una fuente o agencia a los varios medios, donde son expandidas, condensadas, documentadas, ilustradas, elaboradas en múltiples modos para conformar el sentido de aquello de lo que tratan y fomentar el interés de sus receptores - quienes, a su vez, suelen comentarlas y transformarlas de nuevo en sus conversaciones sobre los asuntos públicos, el lugar fundamental de formación de la opinión. Al pensarla desde las cualidades de los relatos, incluyendo esta intrínseca movilidad-mudabilidad, se abren ciertas vías para indagar la forma de participación que prevé en sus receptores, el tipo de conocimiento y de experiencia imaginativa y afectiva del mundo y de los otros que procura la información mediática. Ante el género que nos presenta cotidianamente, en cualesquiera medios, imágenes y sonidos actuales de más allá de nuestro entorno inmediato y que constituye nuestra conexión básica con el ancho mundo, importa preguntarse qué nos da, qué nos niega y qué cabe esperar de él. Observarlo desde una perspectiva pragmática y retórica desde la que cuestionar también si son adecuados a las exigencias de hoy los criterios y valores en que se basa la crítica de la información, como los de objetividad, transparencia, pluralismo e imparcialidad. 
De los relatos o casi-relatos de la información sabemos que producen una insatisfacción general, reiterada tanto en los discursos doctos como en los comunes. Pero también sabemos que la información sigue siendo demandada, aunque en medida decreciente -un decrecer que no parece compensado por el incremento de lectores de los periódicos on line. Y hay buenas razones para considerarla a la vez insatisfactoria y necesaria. No tiene sentido una democracia sin ciudadanos informados sobre las actuaciones de sus representantes. También se atribuye a la información la función de posibilitar el ejercicio de la controversia pública y el control democrático del poder. Es esencial, pues, comprender qué podríamos demandarle. Sin embargo, los discursos críticos, sobre todo desde la teoría política, suelen descalificar globalmente la información mediática, junto con la mediatización de la política, etc., y tratarla como un mal absoluto del que no cabe esperar prácticamente nada. Sospecho que los análisis confunden algo de su estado actual con su naturaleza y que sólo se podría salir del rechazo global de la información ampliando el marco de la reflexión.

Una revisión a la que también nos obliga la intrusión de los medios y recursos on line en la esfera pública, que además de haber dinamitado el "modelo de negocio" de los medios de información, están cambiando profundamente los hábitos de acceso y las relaciones entre productores y receptores (a menudo también periodistas-ciudadanos, participantes en los foros en red fuera y dentro de los propios medios periodísticos, etc.). Algunas voces han puesto grandes esperanzas en la transformación de los públicos, activos participantes en los medios en red, por la interactividad potenciada, unida a la inmensa capacidad de archivo, que estos medios permiten, hasta el punto de que se puede observar una falta de congruencia entre las instituciones políticas existentes y el mayor potencial de interacción comunicativa (Bohman 2010: 251). Sin embargo, varios estudios rebajan el optimismo, al tiempo que señalan que la TV se mantiene como el medio favorito para obtener información política, incluso entre los usuarios habituales de la red, como la mayoría de los jóvenes (Freedman, 2010: 49). Gitlin apunta que casi todos los blogs informativos diarios recopilan sus informaciones de los periódicos digitales y solamente hay en EE.UU. un puñado de webs comprometidas con tareas de "descubrimiento de hechos" o de reporterismo (diferentes de las de simple opinión, comentario o inclusión de textos más o menos bien informados). Los blogs generalmente amalgaman y "enlazan", si bien este autor señala que esta función de enlace es necesaria en un periodismo que permite intervenir a los ciudadanos. Observa además en el auge de blogs, de sitios y webs de opinión una nueva vitalidad del discurso político y una mayor implicación en él, al menos entre los jóvenes (Gitlin, 2011: 96). Varios estudios señalan cómo estos medios se han integrado con los más tradicionales y convencionales potenciando nuevas formas de esfera pública. Castells ha estudiado los movimientos desencadenados por "una chispa de indignación", como las revoluciones de Túnez y Egipto en 2011, el 15M español, Occupy Wall Street, que se originaron por una llamada a la acción desde el espacio de los flujos y que entiende como movimientos virales que transforman la indignación en esperanza "mediante la deliberación en el espacio de autonomía" que construyen en las redes y en las asambleas (Castells, 2012: 214-215), sin olvidar el importante papel que cumplieron, por ejemplo, cadenas de TV como Aljazira en las sublevaciones árabes. En la situación 
de shock y gran ambigüedad informativa que se produjo tras los atentados del $11 \mathrm{M}$ de 2004 en Madrid, Sampedro y López señalan que los foros de discusión, los weblogs y la contra-información, que incluyó, por ejemplo, teléfonos móviles y emisoras convencionales de radio nacionales y extranjeras, se erigieron en medios alternativos con trascendencia en las urnas (Sampedro y López, 2005: 120).

Todo ello apunta al potencial de internet para contribuir a la expansión de la esfera pública, si bien ese potencial depende, escribe Bohman, no sólo de las instituciones que conforman los marcos de la red, sino también de cómo los participantes contestan y cambian esas instituciones y de cómo interpretan internet como espacio público. En fin, depende de la mediación de la agencia, más que de la tecnología (Bohman, 2010: 255). Me inclino por incorporar esas transformaciones y esos medios a un análisis centrado en los espacios y géneros informativos, en su formato de participación y en las dinámicas de sentido y experiencia en las que implican a sus audiencias, entendiendo que a este análisis se asocia la pregunta, siquiera como un horizonte de la indagación, sobre cómo podrían contribuir a la política democrática.

\section{EL PACTO COMUNICATIVO DE LA INFORMACIÓN, O ELARTE DE SER JUEZ Y PARTE}

El género de la información, en webs, radio, papel, TV, tiene siempre la forma de puzzle de variedades que se actualiza permanentemente. La información de la actualidad implica la selección y presentación por parte de los medios de eventos y asuntos sobre lo que sucede en el mundo en el momento de su emisión, o más bien, sobre el continuo hacerse del mundo, ya que esa selección-presentación se actualiza y difunde formando una serie temporal ininterrumpida y en principio ilimitada. En cada composición de la serie se disponen los asuntos más diversos e inconexos entre sí, o bien estos entran y salen del encuadre sin formar un relato conjunto, aunque sí una representación temporalmente continua que varía y en parte se encadena de un día para otro. Se la suele descalificar como info-entretenimiento. Ciertamente, ha de alcanzar un estándar de amenidad, y hasta de emoción, adecuados a las audiencias de hoy, saturadas de espectacularidad. Este es un aspecto de la comunicación informativa que sin duda merece atención, pero no es el único. Esas audiencias quieren, además de entretenimiento y estremecimiento, que la información les haga conocer y comprender algo del mundo y les permita juzgar las actuaciones de sus representantes. El periodismo informativo se hace día a día en esa tensión entre amenidad y fiabilidad. La fijación de la crítica en el aspecto espectacular pierde de vista la productividad de la información, lo que realmente hace este género junto con, o más allá del entretenimiento.

El primer aspecto que parece cuestionar que se pueda identificar la noticia con el relato es la cualidad de la información de dar cuenta del acontecer abierto. La crónica de la actualidad se caracteriza por referirse a unos acontecimientos cuyo desarrollo y resolución son desconocidos (si bien se encuentran en la actualidad informativa abundantes piezas sobre eventos ya concluidos, celebraciones, reuniones periódicas, etc.). Como toda crónica, se ocupa del presente abierto, por definición, 
carente de un final previsto, mientras el relato, en el sentido clásico y común, construye una trama que indefectiblemente camina hacia su conclusión, el cierre narrativo esencial para el sentido global de tal narración. Hasta el punto de que a menudo se entiende sólo retrospectivamente, tomando el final como clave de un sentido que estaba ahí, que era inmanente al relato desde el principio (White, 1992). Refiriéndose a la crónica histórica escribe White:

La crónica a menudo parece querer contar una historia, aspira a la narratividad, pero característicamente no lo consigue. Más específicamente, la crónica suele caracterizarse por el fracaso en conseguir el cierre narrativo. Más que concluir la historia suele terminarla simplemente. Empieza a contarla pero se quiebra in media res, en el propio presente del autor de la crónica; deja las cosas sin resolver o, más bien, las deja sin resolver de forma similar a la historia. (White, 1992: 21)

Lo que hace posible una representación narrativa de los acontecimientos reales es, sostiene White, la clasificación de esos acontecimientos con respecto a su significación para la cultura o grupo que está escribiendo su propia historia, lo que a su vez requiere una noción de centro social desde la cual organizarlos y dotarles de significación ética o moral. Toda narración "es una especie de alegoría, apunta a una moraleja o dota a los acontecimientos, reales o imaginarios, de una significación que no poseen como mera secuencia" (White, 1992: 29). Para este autor, por tanto, la crónica carecería de la dimensión valorativa que toda narración conlleva y sobre la que tendremos que volver.

La crónica informativa que encontramos en cualquier medio, a menudo, aunque ni mucho menos siempre, nos introduce in media res, en medio de los asuntos que acaban de ocurrir o están ocurriendo, lo que, según White, no requiere adoptar una perspectiva valorativa. Pero los únicos ejemplos que aporta este autor de crónica histórica "pura" son los anales, listados medievales de años y hechos (del tipo de los Anales de Saint Gall: "712. Inundaciones por doquier. 714. Murió Pipino, mayor del palacio. 718. Carlos devastó a los sajones, causando gran destrucción") Parece difícil encontrar otras formas de crónica que puedan eludir por completo dar a la presentación de los hechos una orientación de valor.

Si miramos a la información mediática vemos que incluso allí donde adopta el estilo de la crónica, respetando el sentido abierto del acontecimiento, no deja de apuntar a ciertas formas de cierre narrativo. En entornos como los nuestros se encuentra una pluralidad de medios formando un sistema de diferencias y semejanzas. Podemos ver fácilmente, si contrastamos unos medios con otros, cómo el mismo hecho puede adquirir una significación muy diversa en las varias cabeceras, pues cada medio organiza la presentación verbal y visual de la información de forma que sugiere cierta diferencia respecto a los otros (Lorusso y Violi hablan de los diferentes relatos de cada periódico o medio de información, 2004: 81). Son esas dife rencias las que orientan la selección de las audiencias. Donde hay opciones -lo que hoy se entiende como mercado abierto-, cada receptor elige para informarse aquel medio que se halle más próximo a sus ideas y gustos, que confirme sus preferencias ideológicas, políticas, culturales, etc. 
La inclinación ideológica ¿contradice la objetividad que, en línea de principio, debe regir este género? Si seguimos atendiendo a la relación de los medios con las audiencias hemos de suponer que se demanda a la información cierto nivel de objetividad e imparcialidad y que estas siguen siendo guías que diferencian este macrogénero de otros, aunque la mayor parte de las personas sensatas considera problemático hasta qué punto o en qué modo son tales cualidades ideales realizables. Pero simultáneamente se le demanda también parcialidad al medio informativo de propia elección: que esté de nuestra parte, que documente y legitime la perspectiva que preferimos y que marca nuestra visión del mundo común. La información se define como el género que trata de lo real actual de un modo fiable y reproducible. Si tiene algún sentido que siga habiendo información es porque su diferencia respecto de otros géneros o macrogéneros mediáticos aporta algo distintivo y valioso. Su diferencia está en su objeto y su modo. En cuanto al modo, la objetividad y la imparcialidad, aún como máscara, forman parte necesariamente del pacto comunicativo de la información con su destinatario -pues este a su vez ha de poder utilizar tales informaciones como fiables, tanto para formar su juicio como para discutirlo con otros. Lo cierto es que cada receptor elige su sesgo, el que le pide a su medio favorito, al tiempo que busca conocer algo del mundo, darse recursos para juzgarlo y para compartir o discutir sus juicios.

Es difícil saber qué se entiende socialmente por fiabilidad y objetividad. Las reglas del periodismo presuponen que aunque la objetividad absoluta fuera inalcanzable es posible, sin embargo, acercarse a ella en algún grado siguiendo los procedimientos socialmente contrastados para ello -y considerados fundamentales en el periodismo "de calidad" (descritos, por ejemplo, en el trabajo etnográfico de Tuchman, 1999, si bien esta autora difiere de lo que aquí sostengo, pues considera la objetividad como un ritual estratégico de los periodistas, lo que para ella significa un conjunto de recursos para protegerse de las posibles críticas). El periodismo, como las disciplinas que estudian los asuntos humanos y sociales, se encuentra con grandes dificultades ante la noción de objetividad, frente a la imposibilidad de entenderla como captura rigurosa y metodológicamente controlada de un sentido que está "ya ahí", "dado" en el mundo. Inevitablemente esas disciplinas han de cuestionar que se pueda dar en los saberes humanos un conocimiento sin mediación de una perspectiva (Borutti, 1999: 66) o, como dice Ricoeur, sin mediación interpretante (Ricoeur, 219 n. 1).

Sin embargo, no podemos olvidar que si la objetividad no existe respecto al sentido de los asuntos humanos como observación pura, exenta de la parcialidad propia de todo sistema de sentido particular, eso no significa que renunciemos a ella, como a la imparcialidad, en las interacciones y prácticas cotidianas -dejando aparte terrenos como el conocimiento científico o el procedimiento judicial, por ejemplo, que definen sus propios criterios y reglas de objetivación. En múltiples modos, y en forma siempre impura e incompleta, esas cualidades, objetividad e imparcialidad, se encuentran en los más comunes rituales sociales - pongamos las negociaciones y los juegos que, o bien nombran un árbitro, o bien se hacen posibles porque todos los participantes aceptan reglas comunes y asumen cierto grado de imparcialidad en las discusiones sobre los tantos respectivos. La imparcialidad, como dice Krause (2008), 
es una experiencia común. Vivir en sociedad implica crear espacios y formas de acuerdo basados en reglas comunes, que son en todas partes pautas para simplificar y hacer posibles los encuentros. Entre las reglas de la más básica de las interacciones humanas, la conversación (Grice, 1991: 516), se encuentra precisamente la de "sinceridad", entendida como la disposición a responder de las propias afirmaciones, a ser confiable en este punto (otras reglas se pueden considerar de economía - no decir mucho más ni menos de lo necesario, o ser pertinente respecto al asunto del que se habla). Si algo nos enseña la pragmática es que interaccionamos socialmente porque construimos conjuntamente reglas ad hoc y nos damos pautas básicas para actuar e interpretar lo que ocurre.

Si entendemos que la información es necesaria para la democracia; si el periodismo ha de perdurar como práctica, le es imprescindible acordar y respetar ciertas reglas, establecer un pacto de sentido con su audiencia. La información desarrolla las artes y la retórica de la objetividad y la imparcialidad, sirviendo con ello, tanto a la posibilidad de un espacio de información y controversia política, un juego con reglas aceptadas por todos, como a los sesgos de los diferentes sujetos y empresas de comunicación. El análisis semiótico muestra cómo opta por estrategias orientadas a cancelar la perspectiva desde la que se enuncia (Lorusso y Violi lo denominan "enmascaramiento objetivante" y analizan las estrategias del discurso objetivante en artículos periodísticos, 2004: 106). Sin embargo, las informaciones y opiniones (formalmente separadas o bien confundidas en un mismo discurso) de nuestro medio favorito sugieren que hay modos mejores y peores de resolver los asuntos comunes, que hay posibilidades, perspectivas, opciones políticas buenas y malas para organizar nuestro mundo. Es decir, sugieren relatos -en el sentido de White- que organizan los asuntos desde una perspectiva valorativa, siempre parcial y discutible. Por ello hay que admitir que el medio informativo actúa como juez y parte, seguramente en respuesta a la doble demanda de su audiencia, que requiere de los casi-relatos de la información que le aporten algo útil para pertenecer a nuestro mundo, la posibilidad de juzgarlo y de ser partidaria de unas perspectivas u otras, si bien manteniendo el supuesto de que se forma, o se puede formar, una visión objetiva e imparcial.

En cuanto al respeto de las reglas del buen hacer periodístico hay que señalar que los periódicos, al igual que las cadenas televisivas generales y locales, han perdido en gran parte la confianza de los públicos y este, según Gitlin, es el problema más profundo de la actual crisis del periodismo. Entre las causas de esta pérdida de credibilidad menciona este autor "errores devastadores" como la información de los medios de EE.UU. sobre la guerra de Irak. "Los mea culpa oficiales en The New York Times y en el Washington Post solamente aparecieron a posteriori, reconociendo cómo las informaciones se maquillaron, cómo 'la política deformó la inteligencia de los hechos', porque los periodistas no dudaron en secundar al gobierno". Ve otra muestra de la dependencia informativa respecto de las autoridades en el reciente seguimiento periodístico de la crisis financiera, en el que "la inmensa mayoría de los artículos de la supuestamente crítica prensa financiera han venido tratando la burbuja inmobiliaria como si fuera un milagro de la naturaleza". Aquí la información secundó a otros poderes, que le brindaron su "capacidad para oscurecer la proliferación de artimañas insensatas en nombre de una supuesta racionalidad ilimi- 
tada del mercado, que ha sido considerada definitiva por los periodistas." (Gitlin 2011: 98).

Nos encontramos con una esfera pública en una situación paradójica, en que los medios informativos están faltos de credibilidad $\mathrm{y}$, sin embargo, siguen siendo demandados, especialmente la TV, que conforma aún hoy el primer plano de la escena pública. Los mencionados ejemplos de malas prácticas periodísticas demostrarían, junto a la quiebra de los valores profesionales, la pérdida de sentido del periodismo y la información como práctica social, de la que hoy la ciudadanía y los mismos profesionales no esperan que cumpla las reglas del juego o ignoran qué se le puede demandar. Lo que hace necesario preguntarse si ha cambiado el pacto de la información con su audiencia y si podemos prescindir de ese mediador, el periodismo entrenado en las reglas del buen hacer, como parte fundamental de la esfera pública.

La vigilancia respecto a las reglas que definen el juego compartido no es inútil. Como en todas las interacciones humanas, esa vigilancia es imprescindible para mantener el valor del espacio común y las cualidades que lo hacen útil y practicable -si bien el acuerdo sobre las reglas del juego puede cambiar y quizá lo esté haciendo. Pero ese criterio no es suficiente para valorar y criticar la información. Es preciso también tener en cuenta el valor de los relatos que enmarcan la presentación de los hechos y los actores que componen nuestro mundo. Preguntarse cómo entender las demandas de ubicación y de sentido que los impulsan; cómo valorarlos y qué criterios pueden servir para su crítica.

Por otra parte, si la diversidad de perspectivas es fundamental e inerradicable de la esfera pública (como sostiene Arendt) ha de encontrarse también en sus medios de comunicación, manifestada en sus diferentes sesgos. Pero de una diversidad de posiciones encasilladas que no entran en el cuerpo a cuerpo de la controversia, que no reconocen en el diálogo el mérito de las otras perspectivas e intereses sobre algún aspecto del mundo común ¿podemos decir que esa pluralidad contribuye a la conformación de un espacio democrático? Hemos de preguntarnos cómo se hacen públicas las diversas perspectivas sociales sobre los asuntos comunes, cuáles caben, cuáles se excluyen de la pluralidad admitida y si se hace posible una esfera pública de debate y controversia entre ellas.

\section{EL RELATO Y LA EXPERIENCIA DEL RECEPTOR}

La conexión entre la experiencia del receptor y las historias o relatos que recibe ha sido abordada por W. Benjamin, de un modo que no puede ser obviado en la reflexión sobre la información. Aparentemente, los motivos de Benjamin para rechazar que se identifique la práctica informativa con la narración son muy distintos de los de White.

La narración no pretende, como la información, comunicar el puro en-sí de lo acaecido, sino que lo encarna en la vida del relator, para proporcionar a quienes escuchan lo acaecido como experiencia. Así en lo narrado queda el signo del narrador, como la huella de la mano del alfarero sobre la vasija de arcilla (Benjamin, 1986: 92). 
Recordar cómo reaccionaba Benjamin a la información periodística, que consideraba lo más alejado de la narración, aporta un valioso contraste con el supuesto actual de que los medios informativos se dedican a "contar historias", a narrar. Del periódico dice Benjamin que su propósito consiste en excluir rigurosamente los acontecimientos del ámbito en el cual podrían obrar sobre la experiencia del lector. Y en su apoyo cita a Karl Kraus, que "ha demostrado cómo el estilo lingüístico de los periódicos paraliza la imaginación de los lectores" (Benjamin, 1986: 92). ¿Tienen razón Benjamin y Kraus en suponer que la información paraliza la imaginación del receptor y excluye los acontecimientos del ámbito en el cual podrían obrar sobre su experiencia? La experiencia a la que se refiere Benjamin es la que deja su huella en el hábito, en el imaginario, en las pautas impensadas del sentir y el comprender, en la que tienen un papel fundamental la imaginación y los relatos. Según Souza, en la perspectiva de Benjamin, la narrativa guarda las huellas del "sentido común", de las tradiciones, las figuras de lo extraordinario, la oralidad y preserva un carácter práctico o de consejo (Souza, 2013: 31).

Seguramente Benjamin y Kraus consideraban narraciones los relatos sobre hechos acaecidos de Jenofonte, Tucídides, Marco Polo, etc. No es la diferencia entre ficción y no ficción lo que en su visión aleja a la información periodística del relato. Es mas bien el hecho de que la primera "pretende" contar desde ningún lugar, "el puro en sí de lo acaecido", algo que es extraño a la narración, sea de hechos verídicos o ficcionales, sea enunciada en primera o en tercera persona. Ciertas investigaciones posteriores han analizado cómo consigue la narración que el receptor entre imaginativamente en el relato y lo viva como una experiencia. Han observado el poder del relato de introducirnos en una situación extraña, en una experiencia ajena, como un poder que se despliega en varias dimensiones imaginativas, cognitivas, afectivas y éticas, pues la capacidad de hacernos sentir con los personajes está íntimamente vinculada con la de comprender los mundos de sentido y valor, los conflictos que enmarcan sus decisiones (véase Bruner, 1996 y Schaeffer, 1999).

Y aquí volvemos a la cuestión de la dimensión valorativa contenida en el relato, que señalaba White. Toda narración versa sobre la acción de un sujeto que persigue algo de lo que carece o que le es negado. El héroe ha de luchar por alcanzar su objeto de valor, pues el resultado de su intento y del relato mismo ha de ser incierto. Una acción define el valor de un objeto para un sujeto (Greimas y Courtés, 1982: 272 y ss.) y no entendemos su sentido si no somos capaces de ver la relación valorativa que une a sujeto y objeto; no comprendemos el esfuerzo, el conflicto, el logro que supone para el sujeto realizar esa acción (Leone, 2014). Definir un objeto desde la perspectiva de un sujeto, como hace todo relato, implica introducir los sistemas de valores que ese intento pone en juego, el conflicto entre la forma de entender los valores del sujeto y del mundo o de aquello que se le opone. Sólo eso permite que se dé la doble perspectiva propia de todo relato, que por una parte nos presenta la acción y por otra nos hace ver el sentido de la acción para el sujeto (como han mostrado Bruner y Greimas).

Tomemos como ejemplo el conocido relato Johnny cogió su fusil (película de 1971 de Dalton Trumbo, basada en su propia novela), reducido a sus rasgos básicos. Imaginemos que sólo se nos hace saber, o se nos muestra en imagen, que hay un 
cuerpo mutilado en una cama de hospital. Ha perdido brazos, piernas y rostro y ha quedado reducido a un tronco unido a un resto de cráneo. Hasta aquí no es un relato; sólo vemos un hombre terriblemente mutilado en una cama; sólo podemos sentir pena e impotencia. Poco ayuda que nos digan, como hace a menudo la información, que su mutilación ocurrió en la guerra de ciertos unos contra otros, los bandos $\mathrm{X}$ e Y que apenas conocemos.

Como sabemos, el relato sobre Johnny continúa. Una enfermera entiende que no es un mero resto corporal, un muñón insensible, sino que reacciona al calor del sol o a los cuidados. Ella comienza a comunicarse con él y el equipo médico colabora en el intento una vez que comprende la situación real de Johnny. Consiguen preguntarle, utilizando el código Morse, qué quiere. La historia se encamina a un sombrío final cuando Johnny responde que quiere que le dejen morir o bien que le lleven por las ferias y le exhiban como un caso curioso. A los receptores del relato se nos hace saber que Johnny cree que esa es la única forma en que puede no ser gravoso para nadie, siendo como es dependiente de cuidados ajenos, pues de ese modo podría corresponder, pagar esos cuidados. Pero no llega a comunicarla y su motivación no es comprendida por el personal médico que, horrorizado, le cree un monstruo exhibicionista y abandona a Johnny en un depósito. Todo el mundo se desentiende de él, salvo por los cuidados básicos necesarios para mantenerle con "vida".

Como en este caso, la historia puede no tener buenos y malos, pero pone en juego y define un bien y un mal desde la perspectiva de un sujeto. Desde que captamos la situación del joven inválido y entendemos su búsqueda comprendemos el valor que tiene para él. El desenlace de esta historia, a menudo entendida como meramente antibelicista, nos muestra algo más que los horrores de las guerras. Por ejemplo, que el mal mayor para Johnny, incluso superior a la mutilación, es la incomunicación. Podemos pensar, en este caso, en la pobreza del canal y del lenguaje con que contaban los interlocutores, así como en los esquemas interpretativos de los médicos y enfermeras que, al ser incapaces de cuestionarlos, han imposibilitado la comunicación, revelándonos así su precariedad. Es posible, incluso, que Johnny y ese equipo médico compartieran previamente una misma valoración negativa de la eutanasia o de los seres extraños que se exhiben en las ferias, pero Johnny se ha visto obligado a cambiar sus valores, o a jerarquizarlos en un nuevo modo, lo que evidentemente no ha ocurrido a sus interlocutores.

La experiencia inmersiva del receptor en el relato que consigue interesarle es una experiencia real, hecha posible por un mundo virtual, narrativo. La interpretación que se le asocia implica necesariamente algo de lo que el receptor sabe, su enciclopedia, su memoria-experiencia. En ese paso, el receptor capta conflictos y emociones potencialmente muy alejados de los suyos, puede comprender los valores tal como son vividos por esos personajes ajenos a él hasta que los imaginó sintiendo en ese mundo que en el transcurso del relato llega a conocer. En fin, esa experiencia afecta a su conocimiento, sus valores y afectos y puede ampliarlos y cambiarlos (en esto estoy en desacuerdo con Latour -2001-, que sostiene que en la narración el receptor viaja en su imaginación, pero sale inalterado, a diferencia del informe o artículo de investigación científica, en que el receptor obtiene una competencia concreta, ya que puede repro- 
ducir los procedimientos descritos y obtener los resultados presentados por el autor del texto).

Ese poder de ampliar el imaginar, el saber y el sentir del receptor depende de una tradición, del tesoro de lenguajes y formas narrativas que se recrea con cada nuevo relato, y se enriquece gracias a una doble facultad que despliega el receptor de la narración: la de sumergirse en ella para así experimentar mundos de sentido ajenos -el momento de placer de la inmersión, del dejarse llevar en mayor o menor medida por el relato- y la de reflexionar, el segundo momento en que el receptor puede pasar a una actitud distanciada que le permite observar la situación narrada desde otra perspectiva, explorarla cognitiva y valorativamente.

"La narratividad no está desprovista de dimensión normativa, evaluativa, prescriptiva -escribe Ricoeur-. La estrategia de persuasión fomentada por el narrador se orienta a imponer al lector una visión del mundo que no es nunca éticamente neutra, sino que induce implícita o explícitamente una nueva evaluación del mundo y del lector mismo: en este sentido el relato pertenece ya al campo ético en virtud de la pretensión, inseparable de la narración, a la justeza ética" (Ricoeur, 1985: 359). Al igual que hacía Benjamin, Ricoeur apela a la responsabilidad del narrador en el configurar el sentido del relato. Pero podemos ver en un resumen como el de Johnny cogió su fusil que el responsable de organizar el sentido del conflicto sobre el que versa el relato -el enunciador o el narrador de Benjamin y Ricoeur- puede permanecer implícito. El relato presenta la perspectiva valorativa del sujeto protagonista no en el nivel de la voz que enuncia o narra, sino en el de la organización del contenido, el nivel del esquema o la fábula a que es reducido en la forma sintética del resumen. Es la perspectiva inscrita en la presentación de la relación entre el sujeto y su objeto de valor, de sus motivaciones desde su punto de vista. Siempre que el resumen o la síntesis de un relato conserve la doble perspectiva -de la acción, por una parte, y del sentido y valor de esa acción para su sujeto, por otra- vehicula una dimensión valorativa y a menudo el desarrollo del relato se articula en torno a un conflicto de valores. Más aún, induce "una nueva evaluación del mundo y del lector mismo", como ocurre con las narraciones de Adán y Eva y con la de Johnny. Comprender un enunciado como "eso supone comer del árbol prohibido" significa identificar los dos sistemas de evaluación del mundo en conflicto y, según Ricoeur, preguntarse de qué parte de la bifurcación se está.

Los valores no son independientes de los afectos, ya que, como señala Krause, valorar una cosa sobre otras es sentir una preferencia, más que pensar de modo impasible que es mejor. La pasión es la manifestación afectiva del valor. Los valores y preocupaciones básicos son estados afectivos que implican una reflexividad valorativa y un interés y que nos disponen a la decisión y a la acción (Krause, 2008: 8). Por eso, cuando hablamos de valores estamos implicando los afectos que sin duda vehiculan. Krause defiende también la capacidad de transformación emocional posibilitada por recursos como los relatos, que pueden hacernos sentir, desplazar "los límites de nuestra simpatía" para abarcar a seres o situaciones que ignorábamos o que concebíamos desde estereotipos denigratorios que incitaban el rechazo afectivo. En esta línea, Nussbaum escribe que los dramas trágicos llevaban a sus espectadores, desde Grecia hasta Troya, desde el mundo masculino de la guerra al mundo femenino de la 
casa, a que sintieran empatía por los padecimientos de personas cuya suerte nunca podría ser la suya. Y aboga por construir ejercicios similares, capaces de extender la imaginación y la empatía de los ciudadanos. La transformación de las emociones, la capacidad de sentir lo que sucede a otros que no nos son próximos, requiere estimular la imaginación de los receptores, como hace la novela social realista, aportando circunstancias altamente concretas que convierten al receptor "en un habitante de ambos mundos, el privilegiado y el oprimido" (Nussbaum, 2008: 476-477).

Estas autoras coinciden en subrayar la capacidad de apertura de emociones como la simpatía y la empatía. Pero Nussbaum les opone el asco, la vergüenza, la envidia como emociones que nos cierran y contraponen a otros, mientras Krause descarta dividir las emociones en positivas y negativas políticamente (Saiz, 2012) -la simpatía, sostiene esta autora, confirma el statu quo e ignora a los excluidos por el hábito social de sentido. Aboga más bien por comprender la lógica social de las emociones con las que se participa en los mundos sociales y políticos y por evaluarlas, someterlas a juicios valorativos según criterios basados en la racionalidad y en los valores compartidos, como el de reciprocidad o igual respeto. La idea tradicional, reiterada en tantas culturas, de la necesidad de la reflexión sobre las emociones, reaparece. Ninguna novedad en esto, salvo la de mostrar cómo es posible y necesario aplicar esa evaluación de la emoción al campo de las relaciones políticas y la esfera pública.

Es importante aquí observar que el receptor de un relato con frecuencia dialoga en su fuero interno con ese narrador (implícito o explícito) y con su forma de definir la justeza ética -entendiendo el momento reflexivo, al que me he referido como posibilitado por el relato, como una forma de diálogo interior en que el sujeto contrasta diferentes sistemas de sentido y valor. Es la bifurcación de sentidos, de visiones del mundo, que introduce el relato la que aporta al receptor un contraste, por ejemplo entre sumisión y desafío, entre único y múltiple, entre compasivo y cruel, que potencia esa interrogación. Cuando el contraste es de categorías tan básicas que no pueden no afectar a su propio sistema de sentido y valor, el receptor se siente impelido a preguntase por sus creencias y valores.

Sin duda el relato es uno de los más poderosos instrumentos culturales de memoria y experiencia. Construcción de un mundo de sentido dotado de su propio espacio-tiempo, de escenarios y personajes a través de los cuales se amplían los límites de nuestros saberes, valores y afectos. Un recurso público que se puede concentrar en un denso núcleo de sentido o desplegar para mostrar con riqueza de detalle las vidas representadas; se puede repetir, variar y reutilizar para dar sentido al propio mundo y a las experiencias extrañas, propias o ajenas. Un recurso valioso para una esfera pública democrática por la forma de participación, de experiencia del receptor que genera. Por procurar el desplazamiento de la perspectiva propia, así como la percepción de la del otro, por potenciar la reflexividad sobre los valores y sobre la propia implicación afectiva en ellos.

Pero hay que decir que la reflexión a la que invita una narración se amplía con el conocimiento de sistemas alternativos desde los que juzgar los implicados en el relato. Sin esa información sobre visiones y valores diferentes, los relatos pueden confinar a sus receptores en un abanico reducido de sistemas de sentido y de imaginarios. La interpretación que no puede basarse en sistemas alternativos, porque los 
desconoce, está condenada a una reflexión limitada y quizá en algún modo confirmadora del viejo relato y su mundo de sentido.

\section{CASI-RELATOS E IMAGINARIOS DE LA INFORMACIÓN. LOS LÍMITES DE NUESTRO MUNDO}

La pretensión informativa de comunicar desde ningún lugar es una estrategia opuesta a la del relato. Esa estrategia impregna su lenguaje y su expresión, marcados por el supuesto de que la palabra o la imagen pueden ser neutrales y transparentes. Un supuesto que no resiste el análisis sociosemiótico o sociolingüístico. También la sociología del conocimiento entiende, desde Mannheim, que "la palabra y la significación que va ligada a ella es verdaderamente una realidad colectiva" (Mannheim 1976: 137-138) y está condicionada por los sistemas de pensamiento y lenguaje de esa colectividad. Y lo mismo ocurre con la perspectiva de conocimiento, "la manera en que uno observa un objeto, lo que percibe en él y como lo construye en su pensamiento" (1976: 350 cit. por González García 1979: 119). Cada medio informativo describe o narra desde una posición y ese posicionamiento, como ilustraré más adelante, responde a cierta demanda de su audiencia.

La palabra informativa no es, no puede ser neutral, pero sí es forzada a la neutralización de su parcialidad. Se sirve de las tradiciones del periodismo y de los lenguajes objetivadores - pues ninguna palabra puede ser ajena a las tradiciones de alguna época, grupo, tendencia- para cancelar o enmascarar la posición desde la que enuncia. Entre las consecuencias de esta estrategia está el hacer impracticables el diálogo y el debate sobre los asuntos de interés común. La palabra enunciada como desde ningún lugar comunica una versión no como discutible, no como una entre otras posibles, sino como evidencia, como la presentación transparente del "puro en sí de lo acaecido". Por ello, hay que decir que la información tiende al dogmatismo y lo refuerza. Ciertamente, respeta a su modo el principio de imparcialidad, que en los cánones del periodismo consiste en presentar las diferentes versiones sobre un asunto de los agentes reconocidos como tales, por lo que siempre tenemos, respecto a los asuntos de política nacional sobre todo, las perspectivas encontradas de los partidos del gobierno y de la oposición, de los sindicatos mayoritarios, etc. Pero difícilmente dialogan estas perspectivas en el ámbito mediático, antes bien, suelen ser presentadas como rígidas tomas de posición fácilmente dispuestas a descalificar la posición contraria.

En los géneros informativos encontramos toda una gradación de la narratividad, considerada en su capacidad de iluminar las dimensiones cognitivas, valorativas y afectivas de la relación de los sujetos con el mundo y con la acción en que se encuentran trabados, que esquematizaré así:

noR. No relato o casi-relato. Una situación, una acción o una secuencia son presentados sin que comprendamos el mundo de sentido y los valores que explicarían el significado de la situación para los sujetos representados o los motivos de su acción (es el caso ya apuntado de las informaciones e imágenes mediáticas de muer- 
tos y heridos en conflictos bélicos que apenas llegamos a comprender). Sin embargo, la acumulación de no-relatos sobre un mismo sujeto, por ejemplo los inmigrantes, puede conformar un casi-relato o un imaginario que reitera ciertos estereotipos acerca de tales sujetos.

R0. El grado cero del relato es el suceso, el fait divers. Como ya indicaban los semiólogos y los primeros analistas de la comunicación mediática, se trata de la forma princeps de la información de actualidad. Algo maravilloso, descomunal, atroz o sorprendente ha ocurrido. Los humanos se ven atrapados en esta situación que les desborda, donde no caben más explicaciones que las de la coincidencia fatal o las mágicas. (Fernández Romero, 2012: 131 y ss. recoge los pioneros análisis de, entre otros, Barthes y Martín Barbero)

$+\mathrm{R}$. Relato clásico, aquí llamado también pleno, de sujeto que persigue un objeto de valor evidenciando el conflicto de intereses y valores que implica su acción. El reportaje puede ser en el periodismo un ejemplo de relato de búsqueda del conocimiento o de desvelamiento de algo que está oculto a los ojos del público y que puede cambiar su percepción de sujetos o situaciones.

$\mathrm{R}+\mathrm{n}$. El relato implica al receptor de forma que este lo hace suyo, abraza su objeto como una causa, se une a aquellos que persiguen tal objeto y se subsume en el nosotros que los agrupa.

Los varios grados de narratividad, que no están separados tajantemente entre sí, implican una diferente tensión emocional en el receptor. La máxima implicación emocional se da en los relatos que hemos llamado $\mathrm{R}+\mathrm{n}$, relatos del nosotros, como los que enmarcan la participación del propio bando o país en un conflicto. Motivan y respaldan cualquier tipo de acción política colectiva, aunque donde se cierran a las perspectivas de otros y a la posibilidad de diálogo conducen a la polarización, la ceguera respecto de los otros e incluso al fanatismo. El relato oficial de la "guerra contra el terror" que consiguió el respaldo casi unánime de los estadounidenses para la desastrosa guerra de Irak es un ejemplo de este tipo.

Son las formas noR y R0 las que predominan en la información mediática. Los rasgos de los géneros informativos -la apertura en forma de crónica y la neutralización de la posición enunciativa- dificultan que el relato $+R$ se encuentre plenamente en ellos, sobre todo en relación con asuntos que afectan a la construcción del mundo común. Los movimientos o los sujetos que tratan de introducir una cuestión, un issue, en la esfera pública, sí construyen y tratan de comunicar un relato: han de definir un objeto de la acción transformadora que pretenden y su relación con él, como el movimiento ecologista definió entre sus objetivos lograr una reducción de las emisiones de $\mathrm{CO}_{2}$, por ejemplo. $\mathrm{Al}$ hacerlo, además de proponer una medida, ponen en cuestión las formas habituales de actuación, los valores, las visiones del planeta, las leyes, etc. Proponen nuevas concepciones del entorno común, así como una reordenación de valores y prioridades, es decir, configuran una perspectiva cognitiva y valorativa sobre el mundo común. Como sujetos de una acción y de un pro- 
yecto construyen una historia que prevé un final, la consecución de su objeto en un futuro posible y que posee las características del relato clásico $(+\mathrm{R})$, salvo porque su conclusión no se ha producido, si bien está en el horizonte de la acción colectiva y se define más claramente cuanto más el relato se aproxime a la forma $\mathrm{R}+\mathrm{n}$. Como actor, ese sujeto está en el centro de la acción y la percibe como abierta al futuro, a diferencia del espectador del relato que, como decía Arendt, lo recibe acabado.

Los relatos de estos movimientos y los nuevos objetos, asuntos o issues, que promovían e intentaban introducir en los medios tuvieron que romper la frontera de la esfera pública consensuada. Los estudios políticos sobre las sociedades democráticas actuales consideran fundamental el poder inscrito en el "control de la agenda", la capacidad de influir en la configuración de los asuntos públicos, en la agenda de los medios y en la de las instituciones políticas (Lukes 2005), como intentan hacer los movimientos de sectores interesados por un asunto, que han de ejercer cierto contra-poder. Para la discusión sobre la información y la esfera pública es interesante observar que las grandes cuestiones que se han incorporado a los debates públicos en las últimas décadas del siglo Xx -desde movimientos como los ecologistas, feministas, anti-nucleares o los de tipo geopolítico- han sido introducidas por sujetos exteriores a la esfera pública oficial (exteriores a los medios y las instituciones políticas, como señala Habermas 2010: 199). Esos sujetos y movimientos políticos no se han limitado a discutir desde los lugares comunes compartidos, sino que precisamente uno de sus objetivos fundamentales era ponerlos en cuestión, junto con los propios límites de la esfera pública, para proponer la inclusión en el debate de nuevos objetos, nuevos sujetos y sistemas de sentido respecto a los ya consolidados. Esto muestra la relevancia y el carácter de nodo del issue, que conecta las prácticas periodísticas con la construcción del debate público e incluso de los públicos mismos. Y explica por qué la información se organiza en los medios de comunicación en términos de asuntos, issues, que potencialmente afectan e interesan a sus audiencias y que pueden requerir decisiones de parte de los poderes públicos. De ese modo los géneros informativos actúan como parte fundamental de la esfera pública en su papel de mediadores entre los intereses de la ciudadanía, que contribuyen a conformar, y las instancias de decisión política.

Los movimientos innovadores mencionados son valiosos ejemplos de cómo ciertas perspectivas políticas requieren y en ocasiones consiguen ampliar los imaginarios de los públicos y modificar las fronteras de los lugares comunes. Y también muestran cómo esos movimientos han debido comprender las lógicas de los medios para lograr que asuntos y perspectivas antes excluidos adquieran un espacio en ellos (los movimientos ecologistas, por ejemplo, son bien conocidos por sus acciones espectaculares y dramáticas y su habilidad para lograr atención mediática).

El actual lenguaje político muestra un claro reconocimiento del poder del relato, junto con cierto interés por apropiarse de él por parte de los agentes políticos. Una inteligencia asociada a un cálculo de la capacidad del relato de implicar al receptor, de hacerle sentir partícipe de algo que se está haciendo, teóricamente, en su nombre.

Ejemplos de formas narrativas comunes son los ya citados relatos o casi-relatos "oficiales" de la crisis económica, que hoy las poblaciones y buena parte de especialistas descreen abiertamente, o los que se mencionan a menudo en los medios 
como parte del paisaje actual de la crisis política en Europa: el imaginario dominante en Alemania sobre los europeos del sur, muy diferente del relato de los europeos del sur -españoles, italianos, griegos- sobre los alemanes. Torreblanca presenta como síntomas del grave deterioro de las relaciones políticas en Europa "los retratos de Angela Merkel caracterizada como una nazi en las manifestaciones en Atenas o las esvásticas que se vieron en las calles con motivo de su visita a Lisboa. O fíjense, en sentido contrario, en la desgraciada portada de Der Spiegel, la prestigiosa revista alemana, con un montaje en el que presenta un campesino típico del sur de Europa subido en un burro cargado de billetes bajo un paraguas europeo acompañado del titular: 'La mentira de la pobreza, cómo los países en crisis esconden su riqueza"' (Torreblanca, 2013).

No se contrastan entre sí ni dialogan esos imaginarios. Ni a nivel nacional, ni mucho menos a nivel translocal o europeo hay una esfera pública que dé cabida a la discusión abierta entre perspectivas diferentes con vistas a encontrar formas de acción y comprensión comunes. Sin embargo, preguntarse cómo se hacen públicas las diversas perspectivas sociales sobre los asuntos comunes y cómo se realizan las controversias entre ellas, es una cuestión ineludible a la hora de pensar en la calidad de la democracia.

De nuevo, como al comienzo de este trabajo, encontramos en los ejemplos mencionados relatos condensados en imágenes y viñetas o imágenes que sintetizan relatos, o quizá algo menos concluido que la narración en el sentido común del término. Pese a que hasta aquí he explorado un concepto clásico de relato como dotado de cierre narrativo, me encuentro ahora en la necesidad de buscar conceptos más abiertos, o más sensibles a las fronteras borrosas, que permitan abarcar las varias formas que aportan un conocimiento de los mundos sociales incluyendo a sus sujetos, que den acceso a los intereses, las motivaciones, los afectos y valores de los actores, con vistas a enriquecer la reflexión sobre las formas de participación que procura el género informativo.

En el terreno del lenguaje verbal, Boltanski aporta interesantes indicaciones sobre formas de expresión capaces de vehicular afectos, aquellas en las que se encuentran descritos los estados interiores de personas (1993: 80). Esas formas (cuentos, canciones, películas) son básicamente narrativas, aunque no necesariamente son relatos cerrados. Pero señala como fundamental que tales formas cristalicen en imágenes o esquemas, o bien aporten "escenarios paradigmáticos", que permitan el vaivén entre los enunciados y las emociones y puedan favorecer la identificación y el etiquetado de las experiencias emocionales, estabilizadas por la repetición, la re-evocación que las pone en común (Boltanski, 1993: 84).

Ciertas imágenes tienen el poder de mostrar y transmitir las emociones de los sujetos representados. Las autoridades estadounidenses no han olvidado la experiencia de la guerra de Vietnam. La difusión de las imágenes de los niños abrasados por napalm, como sabemos, fue fundamental para cambiar la percepción y la actitud de los públicos de EE.UU. hacia la guerra. Como es sabido, en las guerras posteriores a esta en las que ha intervenido ese país se ha impedido activamente que se tomaran fotografías del país enemigo y de sus habitantes, lo que no ha podido evitar que con el tiempo se difundan también de esas guerras imágenes perturbadoras. Es el caso 
de las fotos de Abu Ghraib, que cuando pasaron de su difusión en red a ser emitidas por TV forzaron la respuesta de las autoridades (Peñamarín, 2009), o el más reciente del video hecho público por Wikileaks en que soldados del ejército USA disparaban sobre civiles iraquíes. Según J. Assange, el hecho de que lo vieran miles de personas forzó al presidente iraquí a exigir a EE.UU. que sus soldados no fueran impunes ante las leyes del país, lo que forzó la salida de EE.UU. de Irak (Evole, 2013).

He utilizado más de una vez el término "imaginario". Por su amplitud y su explícita consideración de las imágenes nos interesa este concepto, también relacionado con la narratividad. Tomando como ejemplos el imaginario del ' 68 , del comunismo, del Mediterráneo y otros, Lorusso (2011) lo entiende como una estructura capaz de cambiar sin perder su identidad que nos proporciona modelos y ejemplos, más que prescripciones, de cómo pensar y sentir respecto de algo. Siguiendo a Wunenburger (2003), define el imaginario como: un conjunto estructurado y coherente de representaciones; con densidad diacrónica; con función modelizante y con un núcleo narrativo. (Lorusso, 2011). Y señala que para Wunenburger, tiene la función de construir comunidad, pues compartir imaginarios es esencial para crear un vínculo comunitario. Los rasgos que atribuye Lorusso al imaginario pueden ser vistos en su aspecto productivo además de descriptivo. Un imaginario permitiría dar coherencia y estructurar un conjunto de representaciones; mantener su continuidad y densidad en el tiempo; proveería un modelo ideacional y emocional respecto de algo, que tendría la capacidad de vincular a los sujetos con los objetos y valores relativos a ese campo representado (como entendemos hace el relato o, en este caso, el más vago núcleo narrativo del imaginario).

Junto a la tensión, siempre irresuelta en el periodismo, entre parcialidad e imparcialidad, objetividad y subjetividad, crónica y relato, he mencionado como clave el posicionamiento de los medios y la ubicación del enunciador y el destinatario del discurso informativo que procuran. Este posicionamiento requiere y construye estructuras de sentido quizá más del orden del imaginario que del relato, entre las cuales señalaré una diferencia fundamental.

\section{PRESENTISMO Y ARRAIGO DE LA INFORMACIÓN}

Una de las críticas más difundidas de la información sostiene que esta nos sitúa en el vértigo del presente continuamente cambiante, acentuado por su puesta en escena, en forma semejante a la del espectáculo de variedades, en que las muy diversas situaciones que aparecen y desaparecen de la escena no forman un sentido conjunto. Cuando alguien se interesa por un asunto está expuesto a que tras una serie de días, desaparezca de la escena, de las pantallas o las páginas, sustituido por otros que los medios han juzgado más relevantes o atractivos. Y no es fácil buscar en otros medios esa información desaparecida, pues generalmente los varios medios coinciden en los criterios de inclusión y exclusión de los asuntos, funcionan como un sistema en el que cada medio observa, monitorea a los otros, para no dejarse desplazar fuera de la definición de la actualidad, la novedad de la que "todos hablan". Cada medio es parte del sistema contemporáneo de medios informativos con los que com- 
pite y colabora en la construcción del "presente de referencia" (como dice Luhmann). Si bien esto cambia, y puede hacerlo aún más con internet y en particular con algunos espacios en red, que facilitan las búsquedas individuales de información por temas o asuntos (Curran y Witschge, 2010: 105).

Esta forma de experiencia inmediatista y fragmentaria se enmarca en la que procura no una pieza aislada, el noticiario, la web o el periódico de un día, sino una sucesión de ellas, pues la continuidad, la permanente actualización es un aspecto constitutivo de este género y fundamental en su recepción. Día tras día el espacio informativo presenta un marco extraordinariamente estable. Visual y/o auditivamente, la información de cada medio mantiene unos mismos marcos de enunciación: entradilla, composición visual o escenario, unos presentadores conservados durante décadas como un capital (de popularidad) de las cadenas de TV. También es marcadamente estable el espacio de referencia, el mapa del mundo que presentan los informativos, en el que coinciden el conjunto de ellos para un mismo sistema o territorio de identificación de la audiencia. Curran y Witschge (2010: 103) señalan que la comprensión del mundo sigue siendo filtrada por un prisma nacional. El interés de los asuntos, que orienta su selección, está claramente delimitado, en primer lugar por lo próximo a "nosotros", el colectivo de pertenencia simbólica de la audiencia-que puede coincidir con la región, para el sistema de medios regionales, la nación para los nacionales, la comunidad translocal, no delimitada por fronteras administrativas, para los internacionales, como CNN, BBC, Aljazira (entendiendo la proximidad no en términos geográficos sino afectivos y simbólicos. Véase Peñamarín, 2008). Esta construcción informativa de un espacio-mundo imaginario del que "nuestra" localidad es el centro afecta a la posibilidad de cooperar con otros en un mundo cada día más interdependiente: los imaginarios del espacio formado por nosotros-y-los-otros, son extraños entre sí, incoherentes y a menudo contrapuestos entre las varias regiones del mundo.

Lo que nos lleva a una diferencia fundamental entre relato e imaginario. Con la narración se dialoga, se discute al menos en el fuero interno de cada receptor, porque su universo contiene un conflicto valorativo del que podemos participar y también porque podemos observar el relato como un artefacto, un objeto de pensamiento exterior a nosotros sobre el que discurrir. En el imaginario, en cambio, nos encontramos inmersos. Está trabado con nuestras creencias, nuestras formas impensadas de valorar y sentir; naturaliza nuestras reacciones, nuestros hábitos afectivos, que vemos confirmados por el acuerdo tácito con nuestra comunidad de sentido -pues, como hemos señalado, el compartir un imaginario crea un vínculo comunitario.

\section{PARA OTRA CRÍTICA DE LA INFORMACIÓN}

Las percepciones, valores y sentimientos de las audiencias están imbricados en sus relatos e imaginarios y cambiar las visiones y afectos requiere intervenir en esas estructuras de sentido. Reclamar atención hacia ellos implica reconocer su valor, pues los conflictos y cualesquiera situaciones de las que se trate de dar cuenta carecen de sentido para el receptor hasta que este los integra en un imaginario o un rela- 
to $\mathrm{y}$, cuando esto ocurre, un conjunto de ideas, imágenes y valores impregna esa situación y la carga de sentido y de afectos, tanto positivos como negativos.

Junto a la función modelizante que los imaginarios comparten con los relatos, su capacidad de crear modelos cognitivos y evaluativo-afectivos, importa señalar su función de frontera cultural: los imaginarios difieren entre las diversas colectividades culturales o subculturales y conllevan estereotipos de los otros diferentes e incluso contrapuestos. Los medios informativos de los países de mayoría islámica, por ejemplo, comparten con nosotros la estructuración cognitiva, afectiva y ética del espacio-mundo, en los ámbitos propio/vecino/extraño, si bien los supuestos que definen esas categorías son en su caso no sólo diferentes de los "nuestros", sino que en buena parte están en conflicto con ellos. Es relevante en un mundo globalizado observar que las audiencias están segregadas como comunidades interpretativas que dan sentido a los hechos desde relatos o imaginarios muy diferentes e incluso enfrentados entre sí.

Comprender esta frontera requiere observar tanto sus formas de estabilización (en la cristalización y consolidación de los estereotipos, por ejemplo) como su dinamismo, los cambios que han producido algún desplazamiento en los límites de lo comúnmente aceptado. Por ello me he referido a los movimientos que han introducido las perspectivas feministas, ecologistas, altermundistas, etc., en la esfera pública y han cambiado con ello sus supuestos básicos y su configuración.

La información es, como la comunicación, estratégica por muchos motivos, quizá sobre todo, por los relatos, imágenes y emociones que mueve y que en gran parte desconocemos cómo abordar. Los casi-relatos sobre el mundo que nos proporcionan los géneros informativos son generalmente, con notables excepciones, ineptos para aproximarnos a la comprensión del mundo común y de la interdependencia global, o incluso perniciosos por inspirar sentimientos de rechazo y confrontación. Necesitamos otros relatos, tanto en la ficción como en la información, que nos permitan conocer el mundo que construimos conjuntamente y comprender a los otros que nos afectan y a quienes afectamos. Y necesitamos una crítica que tenga por objeto, tanto las reglas del juego social de la información, como los recursos semióticos (sobre todo relatos e imaginarios) que conforman nuestros conocimientos, valores y afectos; que considere si éstos se abren para captar las visiones de los otros y dialogar con ellas, para elaborar nuestras emociones y discutir nuestros valores. Una crítica, en fin, atenta a la búsqueda de estrategias y recursos para abrir las controversias públicas sobre el mundo común. 


\section{BIBLIOGRAFÍA}

Benjamin, W., 1986, "Sobre algunos temas en Baudelaire", El programa de la filosofía futura, Barcelona, Planeta.

Bohman, J. 2010 "Expanding dialogue: the internet, the public sphere, and prospects for transnational democracy", en Gripsrud,J., Moe, H., Molanders, A., Murdock, G. (eds.), The idea of the Public Sphere. A reader. Lexington Books, Plymouth, UK.

BoltAnski, L., 1993, La souffrance à distance, Paris, Métailié.

BorutTI, S., 1999, Filosofia delle scienze umane. Le categorie dell'antropologia e della sociologia. Milano, Mondadori.

BRUNER, J. 1996, Realidad mental y mundos posibles. Barcelona, Gedisa.

Butler, J. 2006, Vida precaria. El poder del duelo y la violencia. Buenos Aires, Paidós.

-, 2009, Frames of war. London, Verso.

CAstells, M. 2012, Redes de indignación y esperanza. Madrid, Alianza.

Curran, J. et al, 2009 "Media system, public knowledge and democracy: a comparative study" European Journal of Communication, 24 (1).

Curran, J. y Witschge, T., 2010, "Liberal dreams and the Internet", en Fenton, N. (ed.) New media, old news. Journalism and democracy in the digital age. London, Sage.

ElLis J., 1999, “Television as working-throug”, J. Gripsrud (ed.) Television and common knowledge, London, Routledge,

Évole, J., 2013, Entrevista a Julian Assange, Salvados, La Sexta TV, 19/05/2013

FERnÁNDEZ Romero, D., 2012, Destrucción y reconstrucción de la identidad de mujeres maltratadas: análisis de discursos autobiográficos y de publicidad institucional. Tesis doctoral, UCM < http://eprints.ucm.es/16149/>

FreEdman, D., 2010, “The political economy of the 'new' news environment", en Fenton, N. (ed.) New media, old news. Journalism and democracy in the digital age. London, Sage.

GitLIN, T., 2011, "A surfeit of crisis: circulation, revenue, attention, authority, and deference", en McChesney R. and Pickard, V. (eds.) Will the last reporter please turn out the lights, New York, The New Press.

GonzÁlez García, J. M., 1979, La sociología del conocimiento hoy. Madrid, El espejo.

Greimas, A. J. y Courtés, J., 1982, Semiótica. Diccionario razonado de la teoría del lenguaje. Madrid, Gredos.

GRICE. P. 1991, “Lógica y conversación”, en Valdés, L. M. (ed.) La búsqueda del significado, Madrid, Tecnos.

Habermas, J., 1992, Between facts and norms. Contributions to a discourse theory of law and democracy. Cambridge, Mass.: The Mit Press, en Gripsrud, J., Moe, H., Molanders, A., Murdock, G. (eds.), The idea of the Public Sphere. A reader. Lexington Books, Plymouth, UK, 2010.

Krause, S. H., 2008, Civil passions. Moral sentiment and democratic deliberation. Princeton and Oxford, Princeton U. P.

LAtour, B., 2001, "Piccola filosofia dell'enunciazione”, en Fabbri, P. e Marrone, G. (a cura di), Semiotica in nuce, vol.2,. Roma, Meltemi.

LeONE, M., 2014, "Héroes y antihéroes trans-textuales: el caso Kony 2012”. CIC Cuadernos de Información y Comunicación 19, Universidad Complutense de Madrid.

Lorusso, A. M., 2011, "A Semiotic Approach to the Category of Imaginary", Lexia, 7-8,

Lorusso, A. M., y Violi, P. 2004, Semiotica del testo giornalistico. Bari, Laterza.

Lukes, S. 2005, Power. A radical view. Second edition, New York, Palgrave Macmillan.

MANNHEIM K.1976, Ideología y utopia. Madrid, Aguilar. 
Nussbaum, M. C., 2008, Paisajes del pensamiento. La inteligencia de las emociones. Barcelona, Paidos.

Peñamarín, C. 2008, “¿Hay vida política en el espacio público mediatizado?” CIC Cuadernos de Información y Comunicación, 13, Universidad Complutense de Madrid.

—, 2009, "Comunicación y territorialización. Extraños en Abu Ghraib", en Contreras, F. en Méndez Rubio, A., Silva, V. (eds.) Estudios culturales iberoamericanos. El desierto y la sed. IC. Información y Comunicación, n. 6. Universidad de Sevilla.

Ricoeur, P., 1985, Temps et récit III. Le temps raconté. Paris, Seuil.

SAIZ ECHEZARRETA, V. 2012 "Disposiciones afectivas y cambio social", CIC Cuadernos de Información y Comunicación, 17.

SAMPEDRO, V. y López G., "Deliberación celérica desde la periferia", en Sampedro, V. F. (ed.) 2005, 13-M. Multitudes on line. Madrid, La Catarata.

Schaeffer, J. M., 1999, Pourquoi la fiction?, Paris, Seuil.

Souza Leal, B, 2013, "O jornalismo a luz das narrativas: deslocamentos", en Souza y Carvalho, C. A. de (eds.) Narrativas e poeticas midiáticas. São Paulo, Intermeios.

TorReBlanCA, J. I., 2013, "Mala sangre. La extensión del resentimiento antialemán va de las calles a los pasillos del poder". El País, 3 mayo 2013.

Tuchman,G., 1996, "La objetividad como ritual estratégico: un análisis de las nociones de objetividad de los periodistas". CIC Cuadernos de Información y Comunicación, 4.

White, H. 1992, El contenido de la forma. Barcelona, Paidós.

Wunenburger, J-J., 2003, L'imaginaire. Paris, PUF. 


\title{
RESUMEN
}

Análisis de los relatos que sobre el mundo común realizan los géneros informativos, como componentes fundamentales de la esfera pública. La narración se considera desde su capacidad de hacer que el receptor entre imaginativamente en el conflicto valorativo que plantea. Se sostiene que si el periodismo ha de perdurar como práctica necesaria para la democracia, le es imprescindible acordar y respetar ciertas reglas, como las de objetividad e imparcialidad, que le distinguen de otros géneros mediáticos. Pero las audiencias demandan de la información, junto a cierto respeto por estas reglas, que las ubique en una comunidad de referencia y que adopte una perspectiva, un sesgo, sobre el mundo. Se indaga si aportan los relatos informativos conocimientos y experiencias útiles para comprender nuestro mundo y si contribuyen al diálogo entre perspectivas.

Palabras clave: Información, esfera pública, relato, experiencia, diálogo.

\section{Public sphere and construction of the common world. The dislocated narrative}

\begin{abstract}
The article presents an analysis of the stories about the common world that information genres perform, seen as a key component of the public sphere. The story is considered from its ability to make the receiver enter imaginatively into the value conflict that it poses. It is argued that if journalism is to endure as a practice necessary for democracy, it is imperative to agree about certain rules, like those of objectivity and impartiality, which distinguish it from other media genres. But audiences demand from information media, along with some respect for these rules, that those media locate them in a community and that they adopt a perspective, a bias, about the world. The article investigates whether the news stories provide useful experience and knowledge to understand our world and whether they contribute to the dialogue between perspectives.
\end{abstract}

Keywords: Information, Public Sphere, Narrative, Experience, Dialogue. 